\title{
Balancing The State's Right To Regulate with Foreign Investment Protection: A Perspective Considering Investment Disputes in the South American Region
}

\author{
Maria A. Gwynn*
}

DOI: $10.21827 / 5 b 51 d 545 a 7 b 7 d$

\begin{abstract}
Keywords
INTERNATIONAL INVESTMENTS; INTERNATIONAL ARBITRATION; DISPUTE SETTLEMENT; INVESTOR-STATE DISPUTE SETTLEMENT; SOUTH AMERICA; UNCITRAL; ICSID: MULTILATERAL INVESTMENT COURT; INVESTMET STRATEGIES
\end{abstract}

\begin{abstract}
Some of the challenges in reforming the international investment framework have derived from investor-state disputes, where host states have been sued for environmental or health regulations. Clauses regarding investor-state dispute settlement mechanisms have been therefore improved in modern investment treaties. However, most developing countries, which tend to be most of the host countries to investments, still have Bilateral Investment Treaties from the 1990s where investor-state dispute settlement clauses remain unchanged. This paper analyses different strategies that host countries are taking in light of these challenges. These are particularly noteworthy in the South American region, where one can identify three different approaches concerning the international investment framework. Reflecting on these approaches, the paper addresses the relevance of the multilateral efforts to reform the framework as a way forward, and a more promising strategy, towards the aim of balancing the states and foreign investors' interests.
\end{abstract}

\section{Balancing the Right to Regulate with Investment Protection}

The 'Treaty between two countries concerning the reciprocal Encouragement and Protection of Investment' (what we refer to by the short acronym of BITs), as its name implies, was intended to be used by the parties to encourage investment and mainly to be used as instruments for protection against discriminatory expropriations without compensation. ${ }^{1} \mathrm{We}$ shall focus on the latter because some of the main criticisms of the international investment framework concerned the enforcement of the treaties through investor-state dispute settlement

Maria A. Gwynn. Global Leaders Research Fellow, University of Oxford.

Substantive and procedural minimum standards of treatment also include part of this protection. Dolzer, $\mathrm{R}$ and Stevens, M, Bilateral Investment Treaties (Martinus Nijhoff Publishers, 1995); Salacuse, J and Sullivan, N, "Do BITs really work? An Evaluation of Bilateral Investment Treaties and Their Grand Bargain" 46(1) Harvard International Law Journal (2005) 67, <oxfordscholarship.com/view/10.1093/acprof:oso/978019538 8534.001.0001/acprof-9780195388534-chapter-5> (accessed 27 May 2018). The other aim pertaining to the encouragement of investment will not be dealt with here. For a discussion on different scholarly works on whether BITs increase FDI see summary in Gwynn 2016,128-135. 


\section{Balancing The State's Right To Regulate with Foreign Investment Protection: 111 A Perspective Considering Investment Disputes in The South American Region}

mechanisms, like those laid down by BITs, for restricting host countries in one of their primary rights as sovereigns, i.e. to regulate for the welfare of their citizens as the primary goal. ${ }^{2}$ However, the case remains that investment disputes in which discriminatory actions were taken still exist, and it is only due to the international investment treaty that actors could obtain a remedy for discriminatory expropriations.

We look at the concluded investor-states disputes in the South American region, as it is where both scenarios are shown. ${ }^{3}$ In some cases, BITs have been used in ways that were clearly not intended by host countries when they agreed to them, in a way that restricted a state's freedom to regulate. This is the case resulting from the disputes that involved claims against different kinds of regulations pertaining to an economic crisis, ${ }^{4}$ to protect the environment or the health of citizens.

An example of these issues coming to light is the Philips Morris case against Uruguay. The country was implementing the Framework Convention on Tobacco Control of the WHO, which most countries had agreed to. Uruguay was regulating how big the health warnings on cigarette packages had to be, an action that many other countries in the world had already done, and one that clearly has the health of the countries' citizens at its heart. However, because it had signed a BIT with Switzerland (the home state of Phillip Morris), Uruguay faced an arbitration claim for protecting the health of its citizens, something that Switzerland itself did not have to fear when they introduced the same kind of law for cigarette packages sold in Switzerland. ${ }^{5}$

Regarding environmental regulations, Bolivia, in a case that ended up being settled, had an arbitration claim for terminating a water and sewage services concession in a particular region of its country 'after major violent protests' against that concession. ${ }^{6}$ Chile faced an arbitration claim for US\$2 million for imposing a fishing quota on catches off the

2 See criticism to the investment framework in Van Harten, G, Investment Treaty Arbitration and Public Law (Oxford University Press, 2007); Kaushal, A, "Revisiting History: How the Past Matters for the Present Backlash against the Foreign Investment Regime" 50(2) Harvard International Law Journal (2009) 491, $<$ harvardilj.org/wp-content/uploads/2010/09/HILJ_50-2_Kaushal.pdf >(accessed 27 May 2018); Paulsen, L, "Bounded Rationality and the Diffusion of Modern Investment Treaties" 58 International Studies Quarterly (2014) 1 , < doi.org/10.1111/isqu.12051>(accessed 27 May 2018); Cotula, L, "Do investment treaties unduly constrain regulatory space?" 9 Questions of International Law (2014) 19, < qil-qdi.org/wpcontent/uploads/2014/11/03_Regulatory-Powers-IEL_COTULA.pdf $>$ (accessed 27 May 2018); Bonnitcha, J, Substantive Protections under Investment Treaties: A Legal and Economic Analysis (Cambridge University Press, 2014); Johnson, L and Sachs, L, "The Outsized Costs of Investor-State Dispute Settlement" 16(1) Insights (2016) 10, < ccsi.columbia.edu/files/2016/02/AIB-Insights-Vol.-16-Issue-1-Theoutsized-costs-of-ISDS-Johnson-Sachs-Feb-2016.pdf> (accessed 27 May 2018).

3 Until March 2017, the ICSID Cases database reported 90 concluded cases and 51 pending, totalizing 141 cases in South America. The UNCTAD Investment cases database, which includes arbitration under UNCITRAL rules reported 107 concluded cases and 52 pending cases, totalizing 159 cases in South America.

4 For instance, in the cases brought against Argentina due to its 2001 financial crisis, in addition to dealing with the financial crisis, Argentina, the host country, also had to deal with a foreign investor who acted in its own interest rather than considering the interests of the citizens of the country affected by the crisis. Domestic companies, which were equally affected by the crisis, could not sue the state for how it reacted to the crisis. And yet, BITs allowed foreign investors to do just that.

5 ICSID, Philip Morris Brand Sàrl (Switzerland), Philip Morris Products S.A. (Switzerland) and Abal Hermanos S.A. (Uruguay) $v$ Oriental Republic of Uruguay, Case No ARB/10/7.

6 ICSID, Aguas del Tunari, SA v Republic of Bolivia, Case No ARB/02/3, 73. 
coast of southern Chile. ${ }^{7}$ Ecuador was sued for regulating the exploitation of hydrocarbons in the Ecuadorian Amazon forest. ${ }^{8}$ Peru was sued for denying the construction permit of an investor who wanted a construction of a development in a protected reserve area. ${ }^{9}$ Venezuela lost a case where it was sued after the Ministry of the Environment retracted a construction permit for the investor's facilities to engage in a mining project after declaring it null. ${ }^{10}$ These cases illustrate some of the challenges that state regulation in these areas face.

However, the South American region has also faced investment disputes that were brought against a state on the grounds of governmental nationalisation actions where investors were neither treated according to the provisions stated in the treaty, nor to the minimum standards of international law. Of course, this is the kind of state action that the treaties were primarily designed to protect investors from, namely cases where foreign investors were unjustifiably denied a remedy, or were unable to obtain them locally. However, although the measures affect both domestic and foreign investors, foreign investors could submit their claims to international arbitration through a BIT and have them settled in fair terms. ${ }^{11}$

\section{Table 1. Concluded Investment Disputes in South America (2017)}

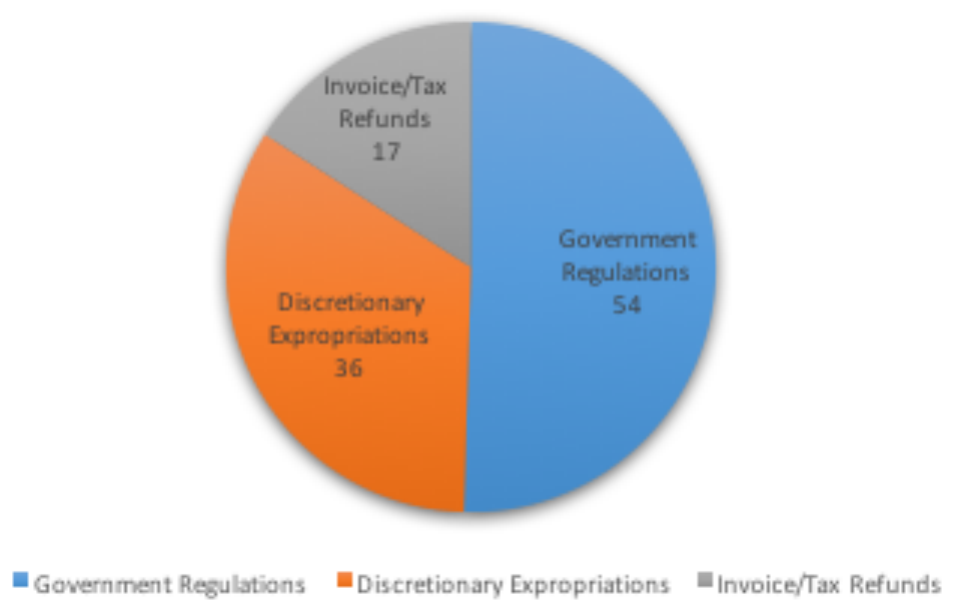

Source: ICSID; UNCTAD, and Host Countries' Institutions investment dispute database. March 2017

The classification is based on the subject matter of the existing investment claims in the South American region: i) arbitration claims against government regulations; ii) arbitration

7 ICSID, Sociedad Anónima Eduardo Vieira v Republic of Chile, Case No ARB/04/7, [Chile won the case but what was awarded was not disclosed].

8 PSA, Murphy exploration v. Ecuador, Case No. 2012-16; ICSID, Occidental Petroleum v Ecuador, Case No $\mathrm{ARB} / 06 / 11$, [In the latter, Ecuador had to compensate the amount of US\$ 1769 millions]; See also PCA, Chevron Corporation and Texaco Petroleum Company v. The Republic of Ecuador (I), Case No 34877, [Decided in favour of Investor].

9 ICSID, Industria Nacional de Alimentos, S.A. and Indalsa Perú, S.A. (formerly Empresas Lucchetti, S.A. and Lucchetti Perú, S.A.) v. Republic of Peru, Case No ARB/03/4, [Decided in favour of State].

10 ICSID, Gold Reserve Inc. v. Bolivarian Republic of Venezuela, Case No ARB(AF)/09/1, [Venezuela had to pay the investor the amount of US\$713 million as compensation].

11 Most examples of these type of cases are those against nationalizations from Bolivia and Venezuela. 


\section{Balancing The State's Right To Regulate with Foreign Investment Protection: 113 A Perspective Considering Investment Disputes in The South American Region}

claims that involved disputes over invoices or tax refunds; iii) discretionary expropriations or expropriations not in accordance to the specifications provided by the treaty or international law.

In this regard, it is important to distinguish international law and what most investment treaties establish, namely that neither state shall expropriate private property, except for reasons concerning: i) public purpose, ii) in a non-discriminatory manner, iii) upon payment of prompt, adequate and effective compensation and iv) in accordance to due process of law. If an expropriation takes place, the four mentioned elements will determine the responsibility of the host state. ${ }^{12}$ Alas, the enforcement of investment treaties for this purpose will always be challenging since the fine line between claims regarding investment disputes and indirect and direct expropriations is difficult to draw.

Against this background, numerous reforms and propositions to change the rules of the international investment framework have been put forward. In the following section, we shall describe the developments to change the rules of the investment framework in the South American region, all of which have taken the form of different kind of strategies that states could pursue to change the framework. These include, actions taken to overcome the challenges by an action involving the termination of the treaties, the creation of a regional arbitration institution to solve investor-state disputes to replace existing institutions, or the alternative to keeping the system as it is. We will assess each of these strategies in light of the purpose of the international investment framework, which concerns the balance between states' right to regulate and foreign investment rules or standards of protection in BITs. In the third section, we shall also compare the propositions contained in modern agreements among industrialized countries with older versions of BITs. Under these considerations, our conclusions address a final strategy relating to the ways that multilateral cooperation and participation in changing the rules at multilateral forums are promisingly less costly for host countries, and would also result in a more balanced outcome for all actors in the framework.

\section{Propositions and Strategies to Change the Investment Framework}

\section{A. Investment-related treaty terminations}

As a result of bilateral investment treaties (BITs) enforcement restricting the right to regulate, some South American countries blamed BITs and the international arbitration institutions, like ICSID, for imposing sovereignty costs on them. Bolivia denounced the ICSID Convention and was excluded from it in 2007, subsequently terminating eight of its BITs. ${ }^{13}$

12 For example in cases against Venezuela and Bolivia, the existence of public demonstrations and protests against the government's expropriation actions question whether the actions were done for a public purpose. See Wall Street Journal, Kurmanaev, A and Forero, J ,Commerce Strike to Protest Venezuelan Regime Fizzles Out, 28 October, 2016, at < wsj.com/articles/commerce-strike-to-protest-venezuelan-regime-fizzlesout-1477681252>(accessed 27 May 2018); Council on Foreign Relations, Lapper, R, Venezuela and the Rise of Chavez: A background Discussion paper, 22 November 2005, at < cfr.org/backgrounder/venezuela-and-risechavez-background-discussion-paper $>$ (accessed 27 May 2018); The Economist, Expropriations in Bolivia. Just when you thought it was safe, 5 May 2012, at < economist.com/node/21554216> (accessed 27 May 2018)

13 Bolivia terminated its BITs with the Netherlands (2009), United States (2012), Spain (2012), Austria (2013), France (2013), Germany (2013), Sweden (2013), Argentina (2014). UNCTAD; Organization of American States. 
Ecuador denounced ICSID in July 2009 and terminated nine BITs, ${ }^{14}$ though the total number of BITs the Ecuadorian President asked to be terminated in that year was thirteen. In 2012, Venezuela also denounced and terminated the ICSID Convention and its BIT with the Netherlands. ${ }^{15}$ Argentina, the South American country against which most investment disputes were submitted to international arbitration, has in fact only paid five of the awards related to its economic crisis of year 2001. ${ }^{16}$ In March 2012, Argentina submitted a draft law in Congress that states the termination of the ICSID Convention. ${ }^{17}$ In 2013, Argentina terminated its BIT with India, in 2014 with Bolivia, and in 2016 with Indonesia. ${ }^{18}$ Chile has terminated its BITs with Korea and Peru. ${ }^{19}$ Brazil, on the other hand, remains reluctant until today to become party to the framework for international investments: it still has not signed the ICSID Convention, nor ratified any modern versions of BITs with industrialised countries. ${ }^{20}$

The termination of the treaties brings to an end all rights and obligations of the parties. This certainly has effects for the host state. The first problem that the host state might face is that the submissions of investment disputes to international arbitration do not end after terminating the treaties or the ICSID Convention. Bilateral Investment Treaties have sunset clauses, which are devised such that the rights and obligations of the treaty remain in force for a certain number of years after the treaty was terminated; the term varies

14 Ecuador terminated its BITs with the Dominican Republic (2008), E1 Salvador (2008), Nicaragua (2008), Paraguay (2008), Romania (2008), Finland (2010), Germany (2010), UK (2010), France (2011). Ecuador's Official Registry No. 632. July 13, 2009; 2011 Investment Climate Statement Report.

US Bureau of Economic, Energy and Business Affairs. March 2011 at <www.state.gov/e/eb/rls/othr/ics/2011/157270.htm> (accessed 27 May 2018); Mena Erazo, P. "Ecuador pone fin a los tratados bilaterales de inversion" BBC News report (September 16, 2010); Ecuador's Legislative Brief No. 179 submitted by the "Comisión de Soberanía, Integración, Relaciones Internacionales, y Seguridad Integral de la Asamblea Nacional" discussed in the sessions dated September 9 and 14, 2010; UNCTAD, Denunciation of the ICSID Convention and BITS: Impact on the Investor-State Claims. IIA Issue note No. 2. December, 2010; A request for termination of the BITs with the US and Spain is pending at the Ecuadorian Congress. Author's translation from the report by Carlos Juliá of the IV Americas Social Forum, on August 12, 2010, < bilaterals.org/spip.php?article17879>.

15 Venezuela denounced the ICSID Convention on January 24, 2012. List of contracting States and Other Signatories of the Convention (as of April 12, 2016) International Centre for Settlement of Investment Disputes.

16 Kluwerarbitrationblog.com, Vetulli, E and Kaufman, E Is Argentina looking for reconciliation with ISDS?, 13 October 13, 2016, at < http://arbitrationblog.kluwerarbitration.com/2016/10/13/is-argentina-looking-forreconciliation-with-isds/>(accessed 27 May 2018); Recently, however, Argentina offered to pay some of these awards in the form of government bonds at a discounted rate. See Investment Treaty News, Calvert, J, State Strategies for the Defence of Domestic Interests in Investor-State Arbitration, 29 Februrary 2016, at < iisd.org/itn/2016/02/29/state-strategies-for-the-defence-of-domestic-interests-in-investor-state-arbitrationjulia-calvert/> (accessed 27 May 2018).

17 Argentina's Draft of Law, File No 1311-D-2012, H Camara de Diputados de la Nacion, March 21, 2012; For ongoing process see Submission of the Lower Chamber of Congress on March, 30 2016. Parliamentary Process 20/2016; Also Senator's Chamber, Communication 134, No 3646, 2016.

18 UNCTAD Investment Policy Hub at <http://investmentpolicyhub.unctad.org/IIA/CountryBits/>

19 Chile terminated its BIT with Korea in 2004 and with Peru in 2009 but replaced them with new treaties. This is also the case for Peru's BITs with Korea and Singapore.

20 Brazil has signed a number of BITs with investor state dispute settlement but it has not ratified any of them; However, Brazil has ratified treaties with some investment provisions with Paraguay in the 1957 and in 1975. 


\section{Balancing The State's Right To Regulate with Foreign Investment Protection: 115 A Perspective Considering Investment Disputes in The South American Region}

from 15 to 20 years. ${ }^{21}$ This is aligned with the protection granted by international law against government measures that might terminate a treaty and give a justifiable way for that government to breach international law. ${ }^{22}$

The second problem concerns the fact that when terminating treaties, the dispute settlement clauses, and recourse to international arbitration, are also terminated. This is a two-fold problem since it would affect the foreign investors, who are also actors of the international investment framework, as well as the host state. The termination strategy would also terminate the protections given by the treaty against unfair discriminatory actions: the third-party international settlement mechanism is one of them.

There are scholars that argue the preference of using only the domestic dispute settlement system, ${ }^{23}$ i.e. courts of the host states and see little advantage on the use of international arbitration because it is claimed that investment disputes have not been depolitized with the international arbitration system. ${ }^{24}$ However, discriminatory actions and disregard for the rule of law normally happen in authoritarian systems, where the domestic courts are equally constrained by authoritative impositions. In such settings, a fair assessment of a dispute is not guaranteed by domestic courts, and thus both aliens and nationals risk abuses or breaches of due process and judicial procedure. Although international law provides protection against such practices ${ }^{25}$ investment treaties make it easier and more straight forward for foreign investors to submit such claims to international arbitration when facing discriminatory actions.

21 Voon, T and Mitchell, A, "Denunciation, Termination and Survival: The Interplay of Treaty Law and International Investment Law" 31 ICSID Review (2016) 413 at <papers.ssrn.com/sol3/papers.cfm?abstract id $=2735974>$ (accessed 27 May 2018).

22 The commentary to Article 13 of the ARSIWA states: "Once responsibility has accrued as a result of an internationally wrongful act, it is not affected by the subsequent termination of the obligation, whether as a result of the termination of the treaty which has been breached or of a change in international law." Commentary to Article 13 of International Law Commission, Draft Articles on Responsibility of States for Internationally Wrongful Acts, November 2001, Supplement No. 10 (A/56/10), chp.IV.E.1 See Nick Gallus The Temporal Scope of Investment Protection Treaties (British Institute of International and Comparative Law 2008); Article 70(1) of the United Nations, Vienna Convention on the Law of Treaties, 23 May 1969, United Nations, Treaty Series, vol. 1155, p. 331; Venezuela for example terminated the ICSID convention in 2012, and yet investment disputes concerning Venezuela are still submitted to ICSID. There are also cases in which the host country's own legal system allows for disputes to continue to be submitted to ICSID.

23 Rogers (2009) and Poulsen (2015) refer to situations of politization of investment disputes because investors involve their home states in such disputes, a situation that international arbitration was supposed to decrease. See Rogers, C, The Future of Investment Arbitration (Oxford University Press, 2009); Poulsen, L, Bounded Rationality and Economic Diplomacy (Cambridge University Press, 2015). Following this line of thought, it is also argued that states should return to diplomacy and 'replace' international arbitration, because the home state intervenes in the host state anyway. Jandhyala has argued that a return to diplomatic intervention of home countries in host countries was preferable, alleging that the former would be more favourable than having a dispute settlement mechanism like that of international arbitration to settle investment disputes. In Jandhyala, S, "Why Do Countries Commit to ISDS for Disputes with Foreign Investors?" 16 AIB Insights 1; Johnson and Sachs (2016) also concluded that having investor-state dispute settlement mechanism in treaties has more costs than benefits for host countries and that that this mechanism is not effective.

24 Gertz, G, Jandhyala, S, Poulsen, L "Legalization, diplomacy, and development: Do investment treaties depolitize investment disputes?" 107 World Development (2018) 239-252.

25 ICJ, Barcelona Traction, Light and Power Co., Ltd. (Belg. v. Spain), ICJ Reports 1970; Paulsson, J, Denial of Justice in International Law (Cambridge University Press, 2005). 
Every international dispute entails political and legal aspects. Having stages in the dispute settlement clauses represents an awareness of this; however, in the practical processes of settling the dispute there are crucial differences among the initial stages of negotiation, mediation, inquiry and conciliation (where, due to political decisions, the resolution of a dispute rests on the parties), and the later stages involving domestic courts or arbitration (where there is adjudication by an impartial third party body). Trying to mitigate disputes at earlier stages has always been common practice established in the peaceful mechanisms of international disputes settlement and has the advantage of reducing party costs. However, if the dispute does not get solved through the previous stages (such as amicable/diplomatic means, negotiation or conciliation or at domestic courts), having recourse to submit the dispute to international arbitration is a very important guarantee. ${ }^{26}$

Concluded investment disputes in South America show that cases where discretionary actions were taken to expropriate without proper compensation still exist. ${ }^{27}$ Although the latter is primarily a concern for foreign investors, terminating the protective component of the treaty could become a problem for the host country if it leads investors to stay away from that country because of fear of arbitrary expropriations. Though Brazil is normally given as an example of a country that does not have this protection, its market size has justified its large amount of investment in spite of this. However, the latest developments and corruption scandals with regard to Odebrecht and Lava Jato make us reconsider the value of a third impartial body; which brings new challenges to the country's reputation, and consequently affects the trust of different investors, nationals or foreigners. ${ }^{28}$

Furthermore, terminating a treaty to rid itself of the sovereignty costs that it brought about due to an international arbitration settlement mechanism may actually bring about higher sovereignty costs, especially in cases where there is power asymmetry. The smaller and weaker a party, the more it would want to rely on legal, fair and impartial institutions in a system that counteracts asymmetric relationships. ${ }^{29}$

26 The Hague Peace Conference of 1899 adopted a Convention on the Pacific Settlement of International Disputes, which recommended different stages to solve a dispute: good offices and mediation, commissions of inquiry, and international arbitration. The practices promoted in such conventions are aligned with investment treaties clauses that have stages to solve the dispute. The investor in its own right can inform their home state of such disputes, it is entirely up to the party to do this, with or without a treaty. Should the home state in furtherance of goodwill choose to try and mediate the dispute -some clauses of investment treaties do not prevent this as there are amicable or negotiation stages to solve the disputes in which there is no restriction as to whom the parties appoint to do this- such practices should be welcome if they contribute to solving a dispute at an earlier stage. In fact, even in the draft constitutive agreement of the Dispute Settlement at UNASUR, there is a reinforcement for the parties to use the previous stages before arbitration to solve the dispute, which is no different from the dispute settlement clauses in investment treaties. For disputes settlement clauses in South American BITs see Gwynn, M.A. Power in the International Investment Framework (Palgrave Macmillan 2016). See also ICSID Convention. Article 26.

27 Some examples are in disputes against Venezuela and Bolivia.

28 Joe Leahy 'A Brazilian bribery machine' Financial Tiles, December 28, 2018 at <https://www.ft.com/content/8edf5b2c-c868-11e6-9043-7e34c07b46ef> accessed 27 May 2018; See also Venezuela for example, which with its government not respecting the rule of law have indeed made that country a less attractive destination for foreign investments. For reputation effects affecting countries, see Kelley, J Scorecard Diplomacy. Grading States to influence their repuration and Behavior (Cambridge University Press 2017).

29 See for example the Itaipu treaty between Brazil and its small neighbouring country Paraguay. Such treaty contains only diplomatic negotiations to solve any dispute and the power asymmetries and dependence of 


\section{B. Replacing the international arbitration institution with a regional institution}

In South America, UNASUR is a regional South American organization which was created with the aim of integrating regional processes developed by the Mercosur and the Andean Community. ${ }^{30}$ Its member states are working on a proposal to create an UNASUR Centre for Settlement of Investment Disputes (UNASUR Arbitration Centre). The main aim of this proposition is to replace the main existing International Centre for the Settlement of Investment Disputes (ICSID), which is dependent of the World Bank.

Immediately after Ecuador terminated its investment treaties and the ICSID Convention, Ecuador's then Foreign Affairs Minister stated that foreign investments will be in danger if Ecuador does not find a new mechanism for dispute settlement. ${ }^{31}$ Indeed, in the year following its ICSID termination, Ecuador submitted a proposal to the recently created South American regional organization, UNASUR, to create a new arbitration centre. Until the proposal of the new centre, it was only Bolivia which had terminated the ICSID Convention in 2007. Ecuador denounced and terminated the ICSID Convention in 2009, and Venezuela denounced ICSID in 2012.

Following these terminations, the host countries made statements putting the blame for the sovereignty costs derived from the investment disputes on particular institutions like ICSID. One of Ecuador's members of Congress stated: 'we are defending the sovereignty of our jurisdiction. We want to acknowledge the possibility that our State has to settle disputes at an instance in which it has confidence. In the case of ICSID our data reveal that its awards have been mainly favourable to the foreign companies' ${ }^{32}$ and the speaker of the Ecuadorian Government further said: 'ICSID works as a tool for exploitation, pressure and destabilization of our countries. ${ }^{33}$ Similarly, in Venezuela, the Energy and Oil Minister reportedly stated: 'We will pull out of ICSID. It is not a mechanism to settle differences and for that reason we will get out of it. ${ }^{34}$ In the case of Brazil, when ICSID Convention was still

the landlocked country Paraguay on Brazil have made it very difficult for Paraguay to advanced or resolved any of the claims that were of national interests for Paraguay.

UNASUR was agreed to in 2008 and entered into force in 2011. It has 'the aim of integrating regional processes developed by the Mercosur and the Andean Community.' UNASUR, History.

31 Interview with Manuel Chiriboga, former Foreign Affairs Minister. In Mena Erazo, P. "Ecuador pone fin a los tratados bilaterales de inversión" BBC News report (September 16, 2010).

32 Interview with Linda Machuca, Vice-President of the International Relations Commission of the Ecuadorian Congress. In Mena Erazo, P. "Ecuador pone fin a los tratados bilaterales de inversión" BBC News report (September 16, 2010).

33 The justification for the termination of these treaties was that they were against the Ecuadorian Constitution. The National Constitution of Ecuador states that the government cannot give away sovereignty when signing international treaties and based on that article Ecuador denounced the treaties. The speaker of Government was Pedro Páez. In the report by Carlos Juliá of the IV Americas Social Forum, on August 12, 2010, at <bilaterals.org/spip.php?article17879>(accessed) (Author's translation) as cited in Gwynn, M, A, Investment Disputes, Sovereignty Costs, and the Strategies of States July 2017, at < geg.ox.ac.uk/sites/geg/files/GEG\%20WP\%20132\%20\%20Investment $\% 20$ Disputes $\% 2$ C $\% 20$ Sovereignty $\%$ 20Costs\%2C\%20and\%20the\%20Strategies\%20of\%20States\%20-\%20Maria\%20A\%20Gwynn_0.pdf> (accessed 27 May 2018).

34 Statement of Rafael Ramirez, Venezuela's Energy and Oil Minister. Agencia Venezolana de Noticias (AVN) (January 15, 2012). 
being drafted in 1964, the Brazilian representative stated that the draft raised constitutional problems, ${ }^{35}$ and until today Brazil rejects the ratification of the ICSID Convention. ${ }^{36}$

Perhaps the perception of ICSID as a common problem, aided by the current institutional structure, made the creation of a regional UNASUR arbitration institution to replace the existing international arbitration institution, ICSID, an appealing one. ${ }^{37}$ In 2012 the first draft of a Constitutive Agreement of the Centre for the Settlement of Investment Disputes of UNASUR was finished; a new version of the draft was presented in 2014. ${ }^{38}$ However, the new agreement is not yet in force since there is no consensus on many matters relating to the creation of such a Centre. ${ }^{39}$

However, there are some aspects relating to the content of the Draft Constitutive Agreement of the UNASUR Centre for the Settlement of Investment Disputes that we should reflect upon if they were used to advance the international investment framework. ${ }^{40}$ The draft starts by stating that the agreement 'shall not affect the applicability of investment disputes settlement mechanism and other obligations contained in international agreements' ${ }^{41}$ This means that even if the draft is agreed upon, there is not going to be any difference in how disputes are handled if they do not modify or terminate their existing agreements. As previously mentioned, the action of terminating the treaties has its disadvantages as well. ${ }^{42}$ Second, the draft states that each party can accept to not submit certain disputes and to exhaust local remedies before a dispute is submitted to the centre. The draft suggestion thus does not differ from what article 26 of the ICSID Convention states in this regard. Third, consultations and negotiations through diplomatic channels are going to be maximized, intending arbitration to only be the last resort. Again, almost all bilateral investment treaties apply the same stages. Interestingly, the draft expressly states the increased effort in using diplomatic channels, which as explained before is in accordance with the existing investment treaties. Furthermore, according to the draft, each member state can object to an arbitrator proposed by the other party, and the objection will prevail over

35 Kalicki, J and Medeiros, S, "Investment Arbitration in Brazil. Revisiting Brazil's Traditional Reluctance Towards ICSID, BITs and Investor-State Arbitration" 24(3) Arbitration International (2008) 432, at < academic.oup.com/arbitration/article-abstract/24/3/423/198906?redirectedFrom=fulltext $>$ (accessed 27 May 2018).

36 It is opposed by Parliamentarians. See Investment Arbitration Reporter 2008, Vol 1 No 9.

37 Though it would also affect some of the UNCITRAL arbitration. For the details of the proposition see Investment Treaty News, Fach, K and Titi, C, Unasur Centre for the Settlement of Investment Disputes: Comments on the Draft Constitutive Agreement, 10 August 2016 at< iisd.org/itn/2016/08/10/unasur-centre-for-thesettlement-of-investment-disputes-comments-on-the-draft-constitutive-agreement-katia-fach-gomezcatharine-titi/> (accessed 27 May 2018).

38 UNASUR VIII Reunion of the Working Group on Investment Dispute Settlement.

39 UNASUR VIII Reunion of the Working Group on Investment Dispute Settlement. March, 2014; Gwynn, M, A, "South American Countries' Bilateral Investment Treaties: A Structuralist Perspective" 6(1) Journal of International Dispute Settlement (2015), 97, at < doi.org/10.1093/jnlids/idv006> (accessed 27 May 2018).

40 Fach, K and Titi, C, Unasur Centre for the Settlement of Investment Disputes: Comments on the Draft Constitutive Agreement , 10 August 2016 at< iisd.org/itn/2016/08/10/unasur-centre-for-the-settlement-of-investmentdisputes-comments-on-the-draft-constitutive-agreement-katia-fach-gomez-catharine-titi/> (accessed 27 May 2018).

41 Article 2, UNASUR Draft Constitutive Agreement of the Centre for the Settlement of Investment Disputes.

42 The draft in its current form does not disarm all the disadvantages that a termination of the ICSID Convention would bring about, which I mentioned in the previous section. 


\section{Balancing The State's Right To Regulate with Foreign Investment Protection: 119 A Perspective Considering Investment Disputes in The South American Region}

nomination of the candidate. ${ }^{43}$ While there have been propositions to establish a Permanent Tribunal, this is only meant to deal with annulments and there is no consensus on the matter. Although there are certain differences among the rules compared to that of ICSID, the UNCITRAL rules or the investment treaties, some of the most prominent features of the current system are kept. Furthermore, in the proposition, the draft retains some of the rules that actors were initially dissatisfied with, which can cause the same effects of the deficient rules of the current framework, such as those resulting in restrictions to regulate. Thus, adopting the latter version of the draft would not significantly improve the current system.

\section{Keeping the system as it is}

Not all South American countries have followed the action of terminating the treaties or the ICSID Convention, and despite being members of institutions like UNASUR, there are some South American countries that are keeping the system such as it is. Moreover, some South American countries continue to promote their countries and provide foreign investors with many incentives to engage in investments in their countries. ${ }^{44}$

Many of the countries in the region not only have the current international legal framework supporting foreign investments but they also have domestic laws that protect foreign investments, even in their national Constitutions. ${ }^{45}$ In many of these investment laws international arbitration is granted as a mechanism to solve disputes. Thus, disputes can be submitted to international arbitration based on domestic investment laws or particular contracts. This has been the case for Ecuador, Peru and Venezuela, countries with cases at different international arbitration institutions based on their investment laws or contracts. ${ }^{46}$

These facts are compatible with global trends. The information of a 2016 UNCTAD report finds 'that at least 108 countries have an investment law as a core instrument to govern investment, almost all of which are either a developing country or an economy in transition' and that such laws 'often cover the same issues as IIAs and more than half of the laws provide access to international arbitration. ${ }^{47}$

The explanation for this strategy of keeping and promoting the international investment system as it is can also be analysed from different perspectives. One could think that countries keeping the system as it is are doing so because they were not yet affected as much by the disputes, contrary to countries that have taken some form of action like Argentina, Bolivia, Ecuador or Venezuela. However, this view cannot be upheld since

43 Article 34, UNASUR Draft Constitutive Agreement of the Centre for the Settlement of Investment Disputes; there are no clarifications to limits to such objections so it could potentially also block the system if it is used in bad faith.

44 See for example the use of Investment Promotion agencies: for example, Red de Importadores y Exportadores (REDIEX) in Paraguay and the ProColombia Centre in Colombia and the one recently created in Chile under their Framework Law for Foreign Invetment. For global trends of countries' investment promotion agencies see UNCTAD, 'Investment Laws: A Widespread Tool for the Promotion and Regulation of Foreign Investment' Investment Policy Monitor (22 November 2016) p 9.

45 See for example the National Constitution of Paraguay, which guarantees equality of treatment between foreign and national investors.

46 See UNCTAD Investment Policy Hub.

47 UNCTAD, 'Investment Laws: A Widespread Tool for the Promotion and Regulation of Foreign Investment' Investment Policy Monitor (22 November 2016). 
almost all countries in the region have experienced investment disputes $;^{48}$ furthermore, as the previous sections showed, they were well aware of the problems faced by other states, of which they are informed at different regional institutions, such as UNASUR.

On a different perspective, Gruber (2000) has claimed that countries will acquiesce to regimes because they know that otherwise the system will proceed without them ${ }^{49}$ However, this is not the only way for states to act and it is proven by the existence of the strategy of replacing the system with other institutions subject to the host countries' regional organization.

An alternative explanation of why countries follow this strategy, therefore, might have to do with the ability of controlling the supply and distribution of credit takes part in shaping outcomes. ${ }^{50}$ Evidence of this sort of interaction has been present since the creation of the framework for international investments and continues to be a factor in the present. Many of the credits from international financial institutions to host countries are coupled to promoting investment policies in those host countries. ${ }^{51}$ This explains how this situation would affect the host country's decision towards preferring such a strategy, since it is a source of revenue.

However, the problem of following this strategy is that by not changing the crucial provisions in such treaties, most of which were signed in the 1990s, the risk of future frivolous disputes does not get mitigated. The Philips Morris case against Uruguay for establishing a health warning is an investment dispute that showcases how this kind of risk still persists if rules were to be left unchanged.

\section{Evolution of Changes in New Versions of Treaties with Investment Provisions}

The current international investment framework has somewhat fulfilled its protective aim for which the rules were designed: it guards investors from discriminatory actions regarding expropriations. However, the enforcement of the early versions of investment treaties also shows that there have been unintended effects that result in sovereignty costs for host states in the form of restrictions to regulate. In order to diminish these sovereignty costs, what has to change are the rules that have such effects.

Considering that none of the aforementioned actions involves an action that effectively modifies the deficient rules of the investment treaties, i.e. those that have caused a restriction to regulate, and considering that protection against discriminatory actions is still needed, it is interesting to note the latest developments to change the rules. Economic shifts have also made industrialised countries subject to some of the restrictions to regulate. ${ }^{52}$ As a consequence, industrialised countries have realised the need to change the rules. The

48 The two exceptions are Brazil and Suriname. See UNCTAD Investment Disputes database and ICSID cases database.

49 Gruber, L, Ruling the World: Power Politics and the Rise of Supranational Institutions (Princeton University Press, 2000).

50 Strange, S, States and Markets (Pinter Publishers Limited 1988).

51 Baccini and Urpelainen (2015) pointed out the "2003 IMF approved a standby agreement worth us $\$ 2.1$ billion intended to bolster Colombia's economic program until 2004" that created the climate for FTAs. Baccini, L and Urpelainen, J Cutting the Gordian Knot of Economic Reform When and How International Institutions Help (Oxford University Press, 2015) 210; see also supra nt 43.

52 Gwynn, M, A, Power in the International Investment Framework (Palgrave Macmillan 2016). 


\section{Balancing The State's Right To Regulate with Foreign Investment Protection: 121 A Perspective Considering Investment Disputes in The South American Region}

European Commission comments on the dispute settlement mechanism of investor-state disputes and states that frivolous claims should be avoided by modifying the provisions of their agreements. ${ }^{53}$ In many of the negotiations of modern investment treaties, the most important changes are pertaining to the two main clauses of investment treaties: expropriations and the dispute settlement mechanism.

Let us take a closer look at the expropriation provision first. BITs established in the 1990s did not contain exclusions on the expropriation clause. As early as 2012, exclusions of regulatory activities from what constitutes expropriation started to appear. For example, in the latest 2012 US BIT model, it is specifically mentioned that state activities protecting the 'legitimate public welfare objectives, such as public health, safety, and the environment, do not constitute indirect expropriations' ${ }^{54}$ In 2016, the EU-Canada Comprehensive Economic Trade Agreement (CETA) explicitly established an article for the right to regulate in the areas of public health, safety, the environment, public morals, social or consumer protection or the promotion and protection of cultural diversity. It further explicitly excluded from the concept of expropriations non-discriminatory measures that are applied to protect legitimate public welfare objectives. Similarly, these same exclusions from the concept of indirect expropriation were recommended to be included in the investment chapter of the Transatlantic Trade and Investment Partnership (TTIP) under negotiation between the US and the EU. (See table below for the evolution of expropriations clauses). If these provisions had been in place in the BITs that South American countries had signed in the 1990s and 2000s, then many of the problematic cases that led South American countries to react against the investment regime could not have been brought to arbitration by foreign investors. $^{55}$

Table 2. Foreign Investment Provisions' Evolution in Expropriations and ISDS clauses

EXPROPRIATION AND COMPENSATION (extracts from the provisions)

SA BITS with the US (1990s): Investments shall not be expropriated or nationalized either directly or indirectly through measures tantamount to expropriation or nationalization ('expropriation-) except for a public purpose; in a non-discriminatory manner; upon payment of prompt, adequate and effective compensation (Traditional BIT clause)

2012 Latest US BIT model: Traditional BIT clause. Addition:

-Clarification for fair market value; excludes compulsory licenses granted in relation to intellectual property rights.

-[Expropriation] shall be interpreted in accordance with Annexes A and B.

Annex B: $[\ldots]$ non-discriminatory regulatory actions by a Party that are designed and applied to protect legitimate public welfare objectives, such as public health, safety, and the environment,

53 European Commission "Investment Protection and Investor-to State Dispute Settlement in EU agreements" 2013; Also, recent suggestions in how to amend the system have introduced changes to allow the host state to counter sue the investor that violates investing in a sustainable manner in the host state. Views expressed in J. Anthony Van Duzer, Penelope Simons and Graham Mayeda Integrating Sustainable Development into International Investment Agreements. A Guide for Developing Country Negotiators (Commonwealth Secretariat 2013).

54 US 2012 Model BIT. Annex B, 4(b).

55 For example, a clear South American case that would not have reached the stage of international arbitration if such provisions were in place is the Phillip Morris case. 


\section{do not constitute indirect expropriations. \\ -Separate articles on Investment and Environment and Labour}

CETA: Traditional BIT clause. Addition:

-Clarification for fair market value; excludes compulsory licenses granted in relation to intellectual property rights;

-Affected investor shall have the right, under the law of the expropriating Party, to a prompt review of its claim, by a judicial or other independent authority.

- the revocation, limitation or creation of intellectual property rights to the extent that these measures are consistent with TRIPS, do not constitute expropriation.

- Article 8.9 right to regulate within their territories to achieve legitimate policy objectives, such as the protection of public health, safety, the environment or public morals, social or consumer protection or the promotion and protection of cultural diversity.

- Annex 8-A: For greater certainty, except in the rare circumstance when the impact of a measure or series of measures is so severe in light of its purpose that it appears manifestly excessive, nondiscriminatory measures of a Party that are designed and applied to protect legitimate public welfare objectives, such as health, safety and the environment, do not constitute indirect expropriations.

CPTPP/TPP propositions (2016): Traditional BIT clause. Addition:

-Nothing in this Chapter shall be construed to prevent a Party from adopting, maintaining or enforcing any measure otherwise consistent with this Chapter that it considers appropriate to ensure that investment activity in its territory is undertaken in a manner sensitive to environmental, health or other regulatory objectives.

\section{TTIP propositions (2016): Traditional BIT clause. Addition:}

-Clarification for fair market value; excludes compulsory licenses granted in relation to intellectual property rights;

- the revocation, limitation or creation of intellectual property rights to the extent that these measures are consistent with TRIPS and Chapter X (Intellectual Property) of this Agreement, do not constitute expropriation.

-ANNEX I: Expropriation .... non-discriminatory measures of a Party that are designed and applied to protect legitimate public welfare objectives, such as the protection of public health, safety, environment or public morals, social or consumer protection or promotion and protection of cultural diversity do not constitute indirect expropriations.

A similar development has taken place in the evolution of dispute settlement clauses: In the 1990s, the Most Favoured Nation (MFN) was applicable to dispute settlement clauses. ${ }^{56}$ Though the latter has not always been accepted by tribunals and in fact has caused great academic debate, due to their application in dispute settlement, such clauses were named 'Frankenstein' treaties, because dispute settlement clauses agreed in third party treaties could be used in a dispute with another party. ${ }^{57}$ In the 2012 US BIT Model, the MFN was excluded from use in dispute settlement clauses. It also included transparency

56 Applied when for the same kind of relation indicated in the same kind of treaty, one country has an advantage, more preference or is placed in a more favourable situation as compared to other countries, then the country that is less favourable can claim MFN and benefit from the rights entitled to other countries under those same circumstances.

57 Price, D, "Chapter 11-Private Party vs Government, Investor-State Dispute Settlement: Frankenstein or Safety Valve" 26 Can-US Law Journal (2000) 107, at < scholarlycommons.law.case.edu/cgi/viewcontent.cgi ?article $=1481 \&$ context $=$ cuslj $>($ accessed 27 May 2018). 


\section{Balancing The State's Right To Regulate with Foreign Investment Protection: 123}

A Perspective Considering Investment Disputes in The South American Region

provisions in investor-state dispute settlement clauses. The inclusion of transparency provisions in the arbitral process was pursued at different levels. ${ }^{58}$ In 2016, CETA excluded the application of MFN treatment from dispute settlement clauses. It introduces a Permanent Tribunal with an Appeals mechanism, transparency, a conduct of proceeding and a code of conduct for arbitrators, and a fast track system for rejecting unfounded or frivolous claims. Also, in CETA the parties had agreed to pursue 'the establishment of a multilateral investment tribunal' (Art 8.29). ${ }^{59}$ Similarly, in the negotiations between the EU and the US, the negotiators proposed to create an 'Investment Court' to make the dispute settlement mechanism evolve much further. ${ }^{60}$ This would involve an appeal mechanism and non-state parties would have better access to the dispute settlement mechanism. (See table below for the evolution of dispute settlement clauses).

Table 3. Evolution of Investor-State dispute settlement clauses.

\section{INVESTOR-STATE DISPUTE SETTLEMENT MECHANISM}

\section{SA BITS with the US (1990s)}

1. Amicably. 2. Consultation or Negotiation. 3. Local Courts, or; 4. International Arbitration (ICSID or UNCITRAL)

\section{Latest US BIT Model}

1.Consultation and Negotiation. 2. Arbitration (ICSID or UNCITRAL).

Clarifies on standards for consent, selection and conduct of arbitrators.

Excluded: Local Courts, MFN from IDS.

Addition: Transparency

CETA

1.Consultation. 2. Mediation. 3. Permanent Investment Tribunal: 15 members nominated by the EU and Canada. ICSID, UNCITRAL rules. Support of ICSID Secretariat. 4. Appellate Tribunal Excluded: MFN for IDS clause; claims if the investment has been made through fraudulent misrepresentation, concealment, corruption, or conduct amounting to an abuse of process; parallel proceedings at domestic courts and the tribunal.

Addition: -The Parties shall pursue with other trading partners the establishment of a multilateral investment tribunal and appellate mechanism for the resolution of investment disputes.

-Rules on the conduct of investment dispute settlement proceedings and Code of Conduct for Arbitrators and -Mediators

-Transparency

-Fast track system for rejecting unfounded or frivolous claims

CPTPP/TPP propositions (2016)

1.Consultation and Negotiation. 2. Arbitration (ICSID or UNCITRAL)

Excluded: MFN from the dispute settlement mechanism

Addition: Transparency

58 See UNCITRAL Rules on Transparency in Treaty-based Investor-State Arbitration, at <www.uncitral.org/pdf/english/texts/arbitration/rules-on-transparency/Rules-on-Transparency-E.pdf> (accessed 27 May 2018).

59 A similar provision was also included in the EU-Vietnam- FTA.

60 See Sornarajah, M, "An International Investment Court: panacea or purgatory?" 180 Columbia FDI Perspectives (2016), at <http://ccsi.columbia.edu/files/2013/10/No-180-Sornarajah-FINAL.pdf> (accessed 27 May 2018), however, claims that an investment court will not cure the illegitimacy of investorstate dispute settlement. He stated that "The establishment of an Investment Court would dissociate that Court from democratic control". 


\section{TTIP propositions (2016)}

1. Investment Court System.

15 judges ( 5 each nationality, 5 third party) Appeal mechanism with 6 panellists.

However, some of the improvements of these clauses are made in agreements among industrialised countries. Developing countries still remain in a great majority host countries to foreign investments. In South America for instance, the ratio of how often a BIT has been used by a foreign investor against a South American host country, as compared to how often South American investors in the counterpart country benefited from the same BIT can show us why it is important to have improvement in the framework that effectively reach host countries. ${ }^{61}$

\section{Table 4. ISDS use in South America}

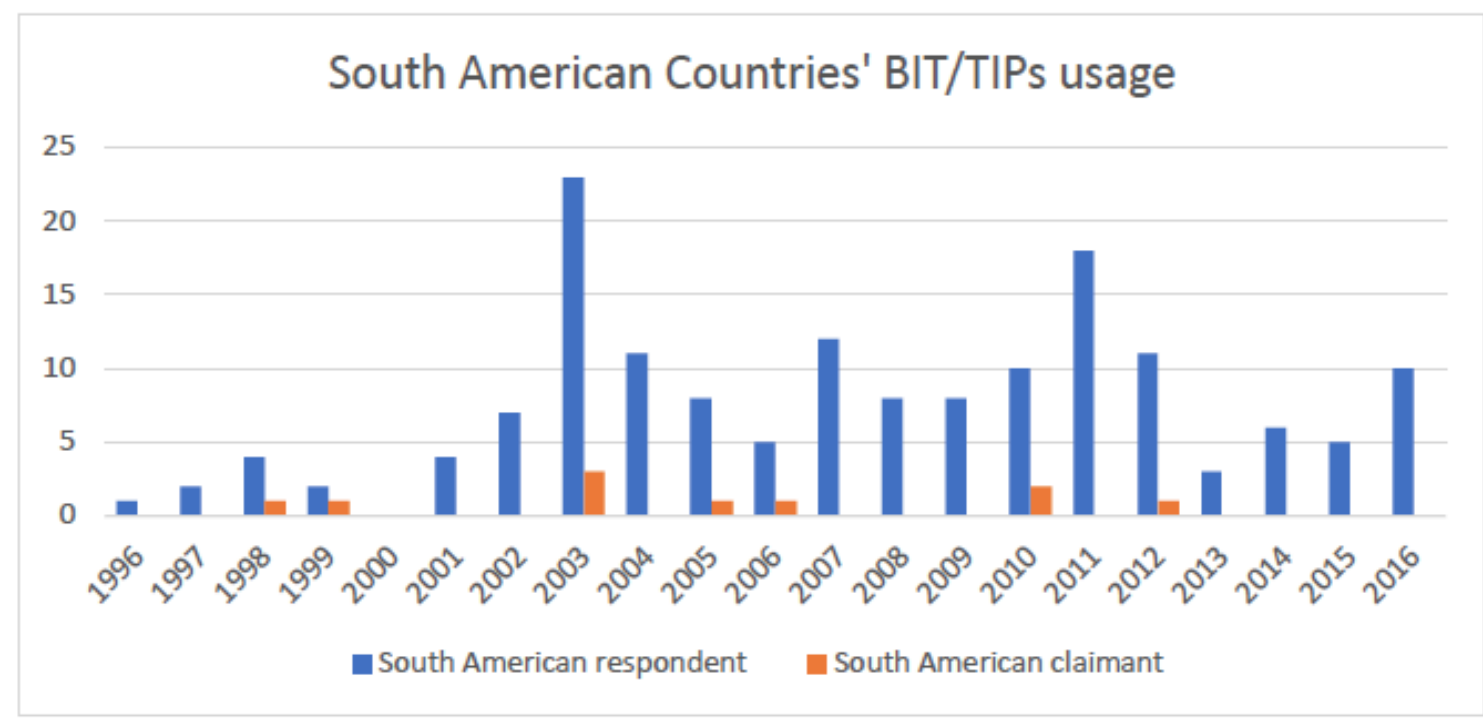

Source: UNCTAD and ICSID investment database.

The enforcement mechanisms in BITs have been used in a greater proportion by foreign investors to sue a host South American state than by South American investors using the same benefit towards the counterpart to the treaties. This of course derives from the difference in investment from South American investors abroad, but it is still important to consider the extent to which host states are affected by the rules of the treaty. For these reasons, when changes and improvement are considered in the international investment framework, those should regard changes that can benefit all actors, states, including developing countries, and also foreign investors. Such is the challenging balance that the framework faces. The herein argument is that such balance can be achieved with the

61 The World bank, Hallward-Dreimeier, M, Do Bilateral Investment Treaties attract FDI? Only a bit...and they could bite, August 2003, at <http://documents.worldbank.org/curated/en/113541468761706209/pdf/multi 0page.pdf> (accessed 27 May 2018) in her study for the World Bank has claimed that there is no reciprocity in BITs, but this claim was made only in regard to FDIs. Since I am giving a prioritized role to the disputes in this analysis, it is important to see the parties' reciprocity in the use of a BIT but in regard to the investorstate dispute settlement clause. 
propositions to reform the framework at the multilateral level, which are explained in the next section.

\section{Towards Multilateral Cooperation and Active Participation in the Changes of the International Investment Framework}

The developments taking place directly at multilateral forums to make some changes to the international investment framework are also very interesting. For example, the work of UNCITRAL in regard to the UNCITRAL Transparency Rules in Investor State disputes in $2014{ }^{62}$ Since its adoption, every arbitration conducted henceforth under UNCITRAL Rules (i.e. derived from BITs concluded after 1 April 2014) must observe the transparency regulations. Transparency rules also establish the creation of a repository, creating a registry of the disputes, all of which becomes available to the public. This information includes the names of the disputing parties, the economic sector involved, the treaty under which the claim is being made, the notice of arbitration, the response to the notice of arbitration, the statement of claim of defence and every other statement or written submission, the exhibits, expert and witness reports, non-disputing party submissions (amicus curiae), transcripts of hearings, orders, decisions and awards. ${ }^{63}$ These are much broader than the institutional rules of ICSID, for example. ${ }^{64}$

However, The UNCITRAL Rules on Transparency entered into force in 2014, but most of the existing investment treaties are dated much earlier. Hence, The UNCITRAL Transparency rules would still have encountered the problem of only being applicable to future investment disputes. However, this was overcome by another keystone development concerning the Mauritius Convention. ${ }^{65}$ The Mauritius Convention establishes that the transparency rules will be applied retroactively to all the investment treaties. In this way, the Mauritius convention acts as a meta-treaty to modify the existing treaties in regard to transparency provision. Signing it is an easy and costless way for a state to modify the provisions of the existing treaties, so as to include transparency provisions in investor state arbitrations. ${ }^{66}$

By a similar token, a multilateral treaty can be used to amend the provisions of existing bilateral treaties and this is exactly what had been proposed at the last UNCITRAL Annual Congress in July 2017. Such changes implemented through a multilateral treaty would have the advantage of avoiding thousands of bilateral renegotiations, since one multilateral treaty can overcome deficiencies like those referred above. Such an agreement may exclude the state's regulatory activities from what constitutes expropriation, exclude MFN from the dispute settlement clause, add transparency to the arbitration process, and

62 UNCITRAL Rules on Transparency in Treaty-based Investor-State Arbitration. Adopted by the UN General Assembly Resolution 68/109 and came into force on April 1, 2014.

63 Article 2 and 3 UNCITRAL Rules on Transparency,. See however, the exception granted to the parties to exclude confidential information in Article 7.

64 Gwynn, M,A, 'UNCITRAL and the Possibility of Returning to the Multilateral Regulation of Foreign Investments' Congress Proceedings Vol 4, 274, at < uncitral.org/pdf/english/congress/1706783_ebook.pdf> (accessed 27 May 2018).

65 UN General Assembly, United Nations Convention on Transparency in Treaty-based Investor-State Arbitration, 10 December 2014, (69 ${ }^{\text {th }}$ Plenary Meeting) A/RES/69/116.

$66 \mathrm{Ibid}$. For a commentary on ratifications of the Mauritius Conventions see Duffy, E "The Mauritius Convention's Entry into Force: High Hopes with Little Impact?" GroJIL blog, May 18, 2017. 
have an improved system to solve disputes. Notably, the changes mentioned here are not an exhaustive list of all that could be changed that affect actors in the framework but they are a first step. ${ }^{67}$

Another important consequence resulting from a multilateral treaty is that many developing countries can benefit from such outcome. The new investment rules changes are seen in negotiations of investment treaties among industrialised countries. Those rules are more advanced but the treaty will only be applicable to those parties. On the other hand, having those new rules in a multilateral treaty is more inclusive as they are open to all developing countries. Furthermore, when such rules containing these specific wordings are enforced, host states will no longer experience the degree of sovereignty costs that were derived from the enforcement of the earlier rules.

Such multilateral agreement may take different forms. Perhaps it will be shaped into an Multilateral Investment Court, which the proposition by the EU Commission asking the council to authorize negotiations in this regards show a close reality to it. ${ }^{68}$ In any event, the latest developments of the rules being proposed in new versions of Treaties with Investment Provisions (TIPs) or implementing those rules through a multilateral convention shall reflect a more balanced approach to the interests of actors in the framework. They prioritize public interests, which is important for any country, powerful or weak. This is also why rather than restricting actions to regional efforts, cooperation on these issues could be more inclusively achieved through multilateral institutional efforts.

Such rules or changes are only targeted at the provisions that have had the effect of restricting the right of a host state to regulate; the protective part is kept. This is another advantage for all actors. Not all the investment disputes have caused sovereignty costs, since many cases were settled ${ }^{69}$ This might point to situations where the host government admits certain behaviour towards foreign investors in which their treatment was not guaranteed as stated in the treaty. Foreign investors can invest in a sustainable manner in host countries while relying on the fact that in case of discriminatory expropriations without compensation a neutral system to settle such disputes exists. Regional integration zones like the European Union and MERCOSUR can equally participate as entities in the framework. Host countries will no longer be prevented from regulating on matters that advance their policies towards the welfare of its people and communities can also be reassured that, as a consequence, their interests are protected.

\section{Conclusion}

Scholars have sometimes referred to winners and losers in the international system and that the losers cooperate because they do not want to be left out of the game, even though they dislike this cooperation. ${ }^{70}$ However, when we consider the institutional structures of international regimes, like those that multilateral forums provide, such institutions also give

67 There is no mention for example of tax revenues and the role of international institutions in that regard, nor is there a contemplation about the impact of advances of technology (automatization) in this area.

68 EU Commission submission of Council's authorization in September 2017.

69 For instance, in 13 nationalization cases against Bolivia, Bolivia settled 12 claims. Similarly, in its 17 nationalization cases against Venezuela, Venezuela settled 12 claims. Cases database in UNCTAD Investment Policy Hub.

70 Specifically, Gruber, L, Ruling the World: Power Politics and the Rise of Supranational Institutions (Princeton University Press, 2000). 
new capabilities to actors. Actors of the international system might face an increased demand for, and reliance on an efficient enforcement mechanism, legitimized by an international treaty acquired in a forum where all interests are dealt with and voices heard, such as one provided by a multilateral forum. This does not mean that cooperation to achieve those aims will be easy, indeed, cooperation can be conflictual, as Keohane (1984) emphasized..$^{71}$ Precisely the ability of a state to adjust to altering conditions is one of the things that characterizes the evolving international system. ${ }^{72}$ Thus, if actors of the international investment framework actively participate in changing the rules in a more balanced way, then those who cooperate with each other to bring it about will be the winners. Better yet, the system in this policy issue area has the potential to overcome the entire dialectic that there have to be winners and losers.

All these changes need active participation to be implemented. Most changes are applied in new versions of International Investment Agreements (IIAs), and for them to have an effect on earlier versions of BITs in force, state action will still be required to pursue and adapt the changes that improve the system. Current developments at UNCITRAL, especially with the Mauritius Convention, show how improving changes can be implemented. ${ }^{73}$ Countries must actively participate and ratify such treaties, or entertain the possibility of agreeing on something multilaterally that follows these changes. It is an easy and costless way for a state to modify the provisions of the existing treaties, as it is for them to improve provisions in investor state arbitrations, avoid the unintended effects and participate in the evolution of the system into something much more balanced, inclusive and with an investment arbitration system that is in accordance with sustainable development.

The worst scenario is that industrialized countries sign improved IIAs with one another, benefit from mutual investments without suffering from sovereignty costs, while host developing countries are left behind because of not changing the rules effectively. Instead, all countries should join the forefront aiming at changing the investment regime, so as to keep all the advantages of the old treaties, but severely reduce the disadvantages, in particular sovereignty costs in the form of restriction to regulate. The changes, once implemented, can provide certainty and security for international commercial relations, which will entail a relationship that is likely to have more long term beneficial effects, and as such will be more propitious for all the actors in the framework.

$*$

www.grojil.org

71 Keohane, R, After Hegemony (Princeton University Press 1984).

72 These ideas have long been pointed out in international relations scholarship, see for example Burton, J, W, International Relations. A General Theory (Cambridge University Press, 1965).

73 UN, 'Settlement of commercial disputes: presentation of a research paper on the Mauritius Convention on Transparency in Treaty-based Investor-State Arbitration as a possible model for further reforms of investorstate dispute settlement' Submitted by the Secretariat on 24 May 2016 for the Commission on International Trade Law Forty-ninth session New York, 27 June-15 July 2016. A/CN.9/890. 